\title{
Corrigendum
}

Cold Spring Harb Symp Quant Biol 79 (2014) doi: 10.1101/sqb.2014.79.024828

\section{Corrigendum: Animal-to-Animal Variability in Neuromodulation and Circuit Function}

\author{
Albert W. Hamood and Eve Marder
}

In the original version of this article, Figure 5B was inadvertently duplicated as Figure 5D. The authors apologize for this error. The correct version of Figure 5 is printed below, and Figure 5 has been replaced in the current PDF version of the article.

A

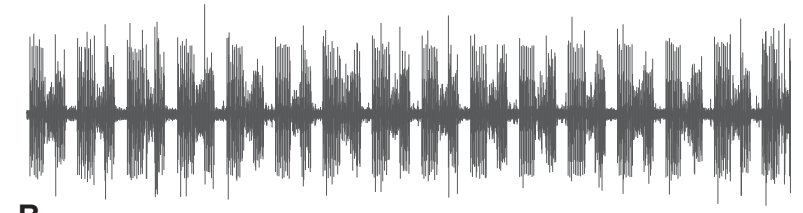

B

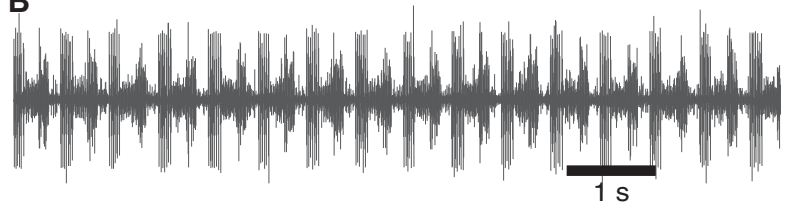

C

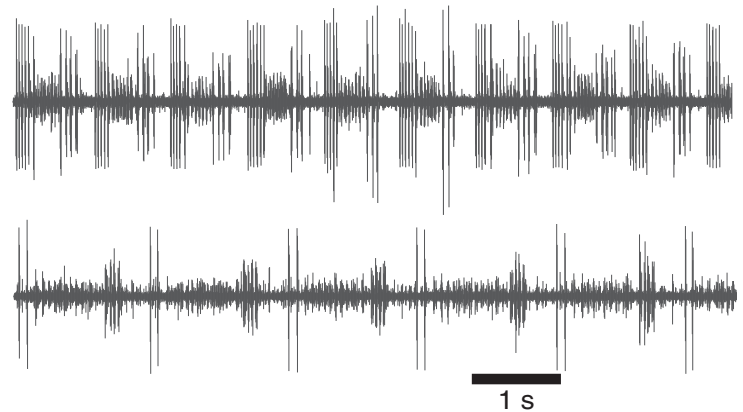

Figure 5. $(A, B)$ Example lvn recordings from two intact preparations of the STNS showing highly similar pyloric rhythms. $(C, D)$ Following decentralization, after $30 \mathrm{~min}$ these same two preparations show highly divergent responses to the perturbation, with dissimilar pyloric rhythms.

doi: $10.1101 / \mathrm{sqb} .2014 .79 .026955$ 


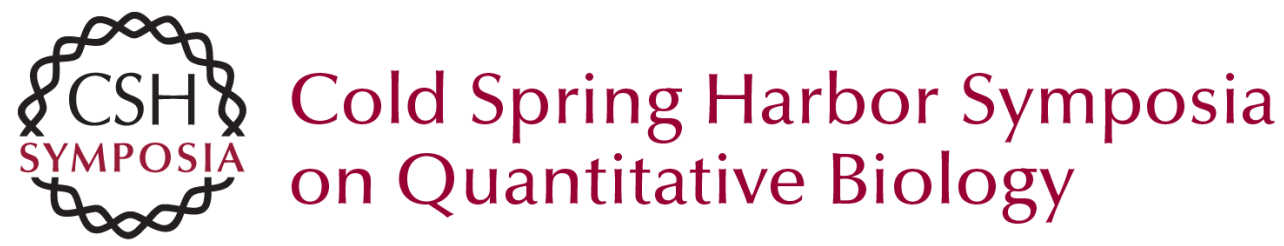

\section{Corrigendum: Animal-to-Animal Variability in Neuromodulation and Circuit Function}

Albert W. Hamood and Eve Marder

Cold Spring Harb Symp Quant Biol 2014 79: 309 originally published online May 6, 2015 Access the most recent version at doi:10.1101/sqb.2014.79.026955

\section{Related Content Animal-to-Animal Variability in Neuromodulation and Circuit Function \\ Albert W. Hamood and Eve Marder \\ Cold Spring Harb Symp Quant Biol UNKNOWN , 2014 79: 21-28}

\section{License}

Email Alerting

Receive free email alerts when new articles cite this article - sign up in Service the box at the top right corner of the article or click here. 